\title{
Fluctuating Anti-Americanism and the Korea-U.S. Alliance
}

\author{
NAE-YOUNG LeE* AND HAN WOOL JEONG"*
}

\begin{abstract}
Rising anti-Americanism in the winter of 2002 despite the increasing security threats from North Koren, has led some to call the situation a crisis in the ROK-U.S. alliance. However, the opinion polls from Junc 2003 and February 2004 show that anti-Americanism in South Korea has substantially waned. The main aim of this paper is to examine whether the recent wave of anti-Americanism has the content and intensity to threaten the legitimacy of the ROK-U.S. alliance. By analyzing the changes in public atritude and perception towards the U.S. over the past two years based on three survey data, this papx:r argues that anti-Americanism in South Korea has not posed any real threat to the alliance. However, the polarized public opinion towards the U.S. remains a potentially serious threat to the future of the ROK-U.S. alliance.
\end{abstract}

Keywords: Anti-Americanism, Korea-U.S. alliance, survcy, public opinion, U.S.-Korca relations, North Korea

- Nae-Young Lee, Associate Professor, Deparment of Political Science, Korea Universiry, 5-1 Anam-dong, Sungbuk-gu, 136-701, Korea; Tel: 82-2-3290-2193; E-mail; nylee(akkorea.ac.kr

" Cartesponding author. Direct all correspondence to Han Wool Jeong, Executive Director, Fast Asia Institute, \#909 Sampoong B/D, 310-68, Euljiro 4 ga, Jung-gu, Seoul, 100-849, Korea; Tel: 82-2-2277-1683; E-1nail: hwjeong@cai.or.kr 


\section{INTRODUCTION}

I

I the meeting on August 11 th with the heads of Unired States Forces Korea (USFK), South Korea's Prime Minister Goh Kun delivered an apology addressing the incident in which Korean student activists had captured a U.S. army tank on August 8, 2003 while protesting for the withdrawal of USFK. He also promised that any re-occurrence would be prevented. The commander of USFK, Leon LaPorte, had requested the Korcan government to punish the organizers of this radical anti-Ametican demonstration, expressing serious concern that the anti-Americanism in Korea would give rise to anti-Korean sentiments in the U.S.

This story shows well that the recent wave of anti-Americanism in South Korca has begun to produce a rift in the Korea-U.S. alliance. While last year was celcbrated as the 50th anniversary of the Republic of Korea (ROK)-L.S. alliance, the state of the bilateral rclations has been deemed at a critical juncture. Since the inauguration of the Roh Moo-hyun government, there have been signs of tension and fissure between the Roh Moo-hyun government and the Bush administration. The victory of Roh Moo-hyun, the candidate of the ruling New Millenium Democratic Millenium Party, has set South Korea and the United States on the most divergent diplomatic paths yet followed in a half century of close military and economic alliances. The difference in approaches between Seoul and Washington concerning the nuclear crisis results from their fundamentally dissimilar perceptions about North Korea. President Roh regards . Vorth Korea as a partner in negotiations, rather than an adversary. His view is in sharp contrast with that of U.S. President George W. Bush, who has branded North Korea as part of an "axis of evil."

Moreover, the recent surge of anti-American sentiments among the Korean public has become a strain to the Korea-U.S. alliance. Anti-Americanism in Korea has suddenly gained visibility since the 'candle light protests' of November and December 2002 in Scoul. The surge of anti-Amcricanism in December 2002 was qualitatively different in its size and duration from previous incidents that manifested anti-Americanism. The anti- $\Lambda$ merican demonstrations that began in June 2002 after the deaths of two schoolgirls continued to expand and in December over 100,000 people nationwide were participating in demonstrations calling for justice ovet the deaths of the school girls and for revision of Korea's Status of Forces Agreement (SOFA). It was by far the largest anti-American demonstration ever in South Korea.

As anti-Americanism was increasing in South Korea, tensions were also rising on the Korean peninsula concerning the North Korean nuclear program. In the past, there had been a general pattern of increased public support for the ROK-U.S. alliance whenever a threat to national security arose.

Figure 1 shows the history of change in public opinion on the withdrawal and reduction of LSFK. We can see that support for USFK has varied according to the progress in the inter-Korean relacions. ${ }^{2}$ In other words, when intcr-Korean relations showed signs of improvement, public opinion favored withdrawal or reduction of 
US armed forces, and whenever there was a securicy threat, public opinion showed support for the presence of USFK. When inter-Korean relations became strained due to North Korea's missile test in 1998, only 38 percent of South Koreans favored the withdrawal or reduction of USFK, but the figure increased to 64 percent in a September 2000 poll that coincided with the post-summit reconciliation betwecn the two Koreas. Then, with the second South-North naval shootout in the summer of 2002 , the percentage of those critical of LSFK dropped to 48 percent.

\section{FIGLRF 1. SUPPORT FOR THE WITHIDRAWAL AND REDUCTION OF USFK}

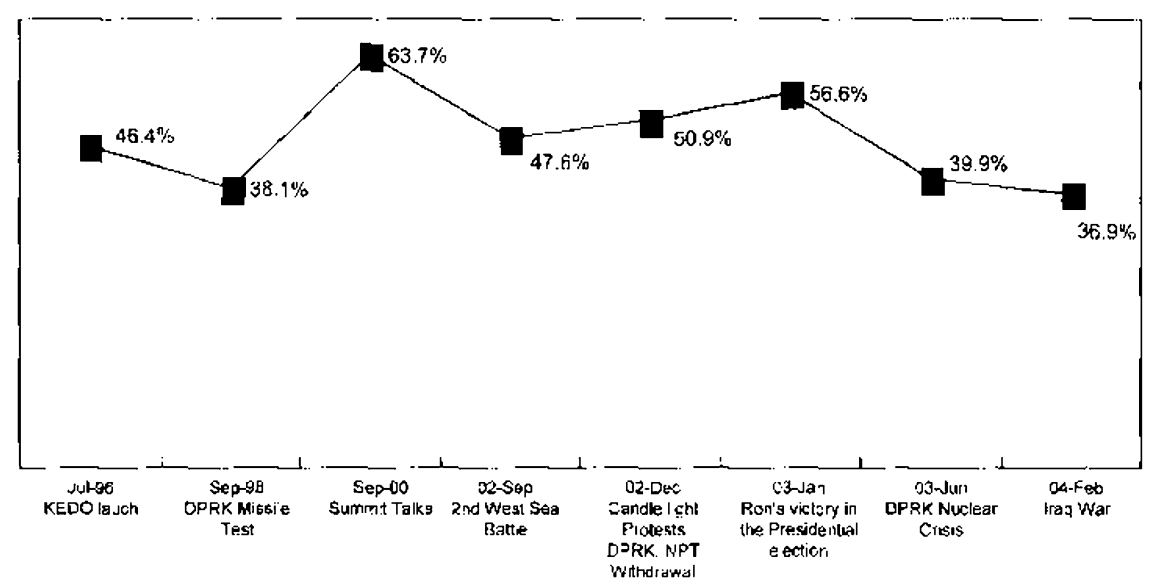

SOURCE: lee and Jeong (2003).

In December 2002, the security threat against the Korean peninsula mounted with Pyongyang's announcement of intentions to resume the nuclear programs, yet there was no sign of waning anti-Amcricanism. In fact, it continued to grow regardless of the nuclear standoff with the North Korca. In other words, the past pattern of increased support for the I.S. ith the presence of a security threat from North Korea no longer held true.

Rising anti-Americanism despite the presence of a security threat from North Korea, has led some to call the situation a crisis in the ROK-U.S. alliance. They argue that anti-Americanism in South Korea will send the American public and L'S. govemment a negative image of South Korea, and could lead to negative political consequences such as a complete withdrawal of the USFK. ${ }^{3}$

'I'he interisity of anti-Americanism in South Korea in the winter of 2002 can be confirmed from a comparative perspective. As Figure 2 shows, according to a global survey data conducted by the PLW Research Center in 2002, Koreans' negative sentiment toward the U.S. rates the highest in Asia and rivals that of some of the Muslim countries. ${ }^{4}$ While lower than that of Pakistan ( $\left.69 \%\right)$, the percentage of South Korea's unfavorable perception toward the U.S. (44\%) stands at a comparable level with that of Bangladesh (47\%). Again, it is distinctively higher than that of any 
other Asian country: Indonesia (36\%), Japan (27\%) and the Philippines (7\%). The even more interesting point is that Koreans' negative sentiments are more intense than in those countries that are formerly Cold-War adversaries, like Russia (33\%) and Vietnam (27\%). Considering the long and intimate security relations between Korea and the U.S., the intensity of the anti-Americanism in Korea is surprisingly high.

FIGLRE 2. U.S. IMAGE: BAD

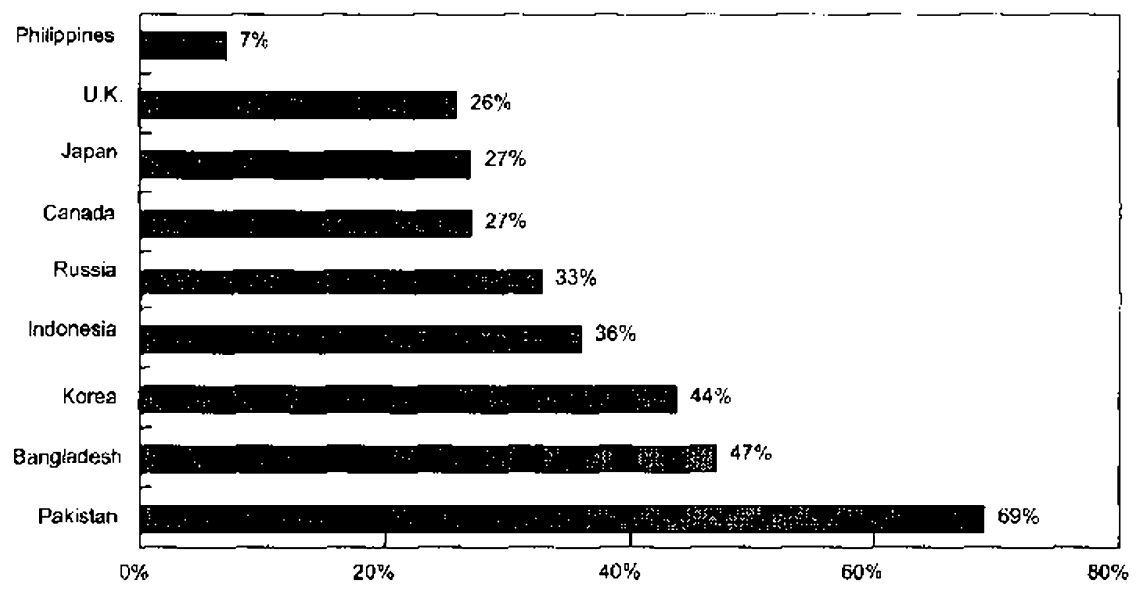

SOLRCE: PEW Research (2OH)3).

Therefore, anti-Americanism in South Korea is expected to remain for a long time as a source of conflict within Korcan sucicty, and may pose an obstacle to ROK-Li.S. relations. However, it is surprising to note that the opinion polls from June 2003 and February 2001 show that anti-Americanism in South Korea has substantially waned. From these polls, public opinion on the ROK-U.S. alliance and USFK has reversed from negative to positive and a favorable perception on the U.S. and the ROK-U.S alliance has increased among the Korean public.

How can we explain and interpret the decline of anti-Americanism during the last two years? The reversal of public opinion shown in the three surveys raises a number of questions: What factors cause the reversal of public opinion towards the United States? Among diverse segments of Korean public, what sector changes the most and why? Has the decline of anti-Americanism also diluted the polarization of public opinion by age groups and ideological positions? Is there a significant change in attitude and perception of the Korean younger generation who have showr the strongest anti-American sentiment in the December 2002 candlelight demonstrations?

The main aim of this paper is to address these questions by examining the changes in public attitude and perception towards the U.S. over the past two years. The 
empirical data used for the paper are based on polls conducted jointly by the East Asia Institute and the Joongang Daily and Hankook Daily, in December 2002, June 2003, and February 2004. Conducted three times with an approximate six-month interval using the same questionnaire, the opinion poll produced ourcomes that are useful in discerning the changes in public attitude towards ROK-U.S. relations. ${ }^{5}$

The major arguments of this paper on anti-Americanism in South Korca, based on the empirical analysis of survey polls, can be summarized as follows. First of all, the poll results show that the wave of anti-American sentiment of December 2002 stemmed from popular discontent with the deaths of the two schoolgirls and with SOFA. Three survey results show that a national consensus has been formed concerning the revision of SOFA. Second, the majority of the Korean public recognized the ROK-L'S. alliance as a deterrent against North Korea, and thus support for the ROK-U.S. alliance and USFK has increased substantially. Therefore, this paper argues that anti-Americanism in South Korean has not posed any real threat to the alliance. Third, in spice of the trend of waning anti-Americanism, the polarization of public attitude towards the U.S. based on age groups and political orientations remains a potentially serious threat to the future of the ROK-U.S. alliance. ${ }^{6}$ I will now provide support for the kcy arguments of this paper based on empirical analysis of chree survey data.

\section{CHANGING ATTITUDE OF THE KOREAN PUBLIC TOWARDS THE U.S.: FROM DECEMBER 2002 TO FEBRUARY 2004}

The rise of anti-Americanism in the winter of 2002 was a temporary outburst fueled by mass candlelight demonstrations and political circumstances surrounding the presidential election. Therefore, it is not clear whether the wave of anti-Americanism has the content and intensity to threaten the legitimacy of the ROK-L.S. alliance. To detcrmine whether anti-Amcricanism of the Korcan public was serious enough to challenge the legitimacy of ROK-U.S. alliance, we need to examine how anti-Americanism in December 2002 has changed since the inauguration of the Roh Moo-hyun government. To do so, I will discern and discuss the change of public attitude towards the U.S. during the last two years, by comparing the results of the three public opinion surveys.

\section{Public Consensus on Revision of SOFA}

The wave of anti-Americanism in the winter of 2002 was triggered by the tragic deaths of the two schoolgirls in June 2002. In its wake, hundreds of thousands of protestors demanded the immediate revision of the unequal provisions contained in SOFA. SOFA was considered a symbol that institutionalized the unequal nature of Korea-U.S. alliance. 
Figure 3 shows the changing atcitude of the Korean public toward SOFA. It indicates that the Korean public has shown unanimous support for the revision of SOFA. The percentages of support for major or partial revision have respectively oscillated between $85 \%$ and $96.2 \%$ since the poll in December 2002. To be more specific, public call for the complete revision of SOFA reached $69.5 \%$ in December 2002 after the U.S. milirary court judged Sergeants Nino and Walker, the two suspects in the homicide of two schoolgirls, not guilty. However, the opinion for the major revision considcrably weakened down to $34.2 \%$ in June 2003 and rose again to $52.4 \%$ in liebruary 2004.

FIGURE 3. SI:PPORT FOR REVISON OF SOFA

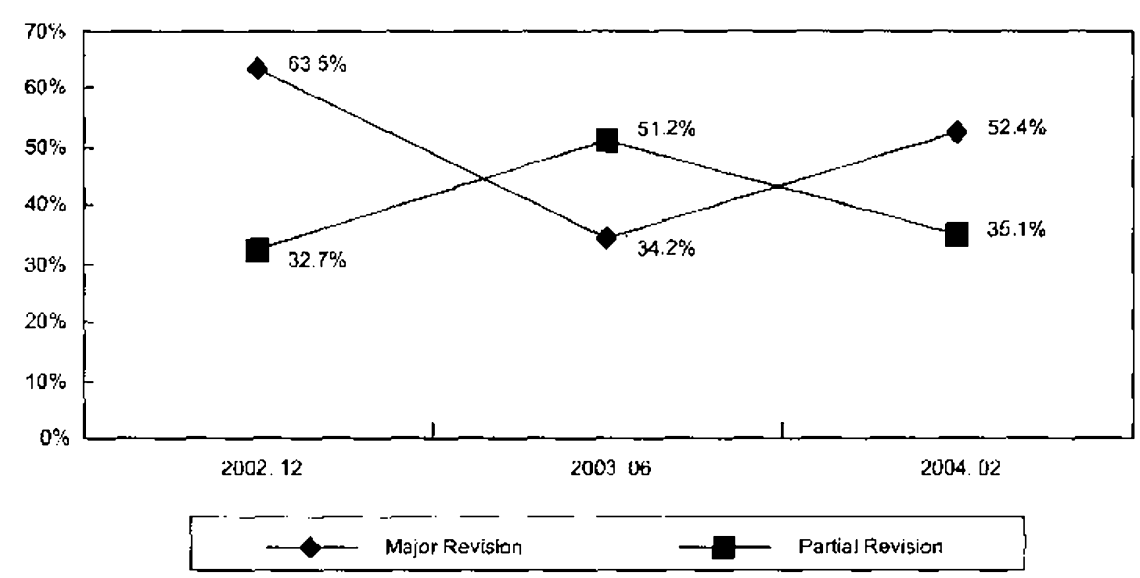

SOURC.: EAI and Joung-Ang Ilbo (2002, 2003) and EAI and Hankook Jlbo (2014).

* Those Responses of "Don' know" and "No response" are excluded.

Nevertheless, we have to notice that rnost Koreans (over 80\%) have kept their negarive attitude toward SOFA and have supported a major or partial rcvision of SOFA. Most Korcans view SOFA as maintaining the core provisions of unfairness such as the serious limit on the range of Korean jurisdiction, the instigation of GI's crimes and the absence of regulations on noisc damage or environmental pollution around training camps and army posts of UJ.S. troops. ? This result indicates that mose Koreans regard the SOFA issuc as a basic human rights issue and demand SOFA revision while supporting Korca-L.S. alliance.

\section{Increasing Support for the ROK-U.S. Alliance}

While public consensus on SOFA revision reflects the rise of anti-American sentiments, it does not justify the claim of a crisis in the ROK-U.S. alliance. ${ }^{8}$ To determine whether the recent rise of anti-Americanism thrcatenced the legitimacy of the ROK-U.S. alliance, we should first look at the public view on issues closely linked to the alliance 
between South Korea and the U.S., and gauge public opinion about the role of LSFK, desired ROK-U.S. relations, and Washington's North Korea policy.

First, let us look at the changing attitude on ROK-U.S relations as shown in Figure 4. When asked what would be a desirable ROK-U.S. alliance, in the December 2002 survey, 20.4 percent supported a stronger alliance and 50.5 percent took the middle-road position of maintaining the current alliance. The remaining 28.1 percent calted for national defense autonomy. It is likely that those who called for national defense autonomy tend to be discontent with the ROK-U.S alliance. In June 2003, however, there was a sharp rise in support for a stronger alliance with the U.S. from 20.4 to 32 percent while those calling for national defensc autonomy dropped from 28.1 to 17.6 percent. This indicates that there has been a significant shift to a favorable attitude toward the IJ.S.

Figure 4. Chatcing; ATtitt:do on ROK-t IS Altiance

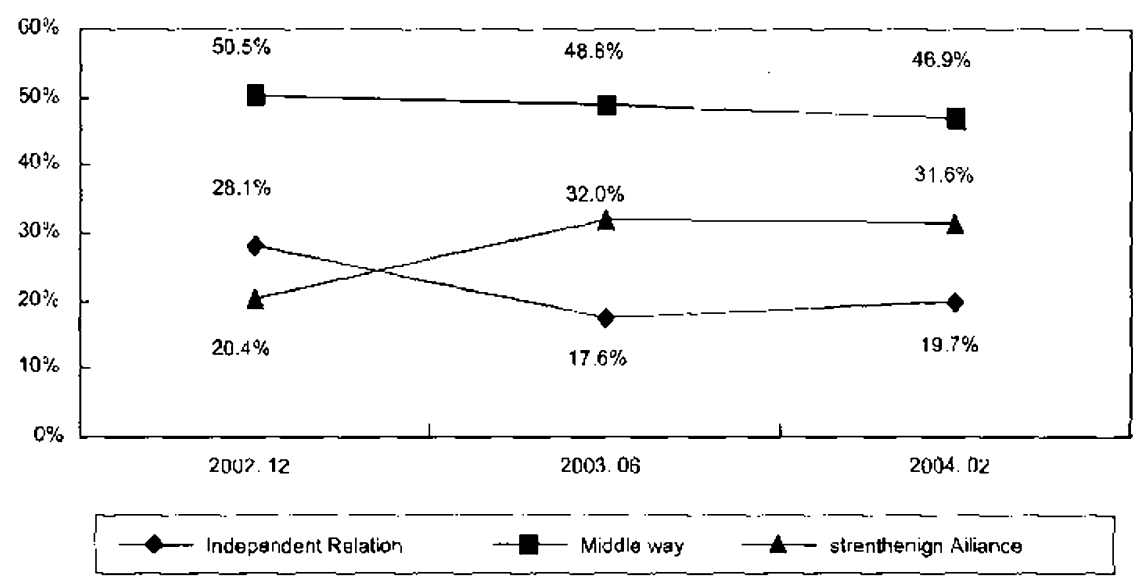

SOURCE: EAI and Jowng Ang Ilbo $(2002,2003)$ and liAI and I lankook Ilbo (2004).

* Those Respomses of "Don't know" and "No response" are excluded.

The increase of favorable attitude toward the U.S. is also observed from the changing perception on USFK. Figure 5 shows the changing attitude of the Korean public towards USFK. In the December 2002 poll, support for "immediate withdrawal" $(6.3 \%)$ and for "staged withdrawal" $(44.6 \%)$ of USFK were higher than support for "continued presence" (27\%) and "extended presence" (21\%). Considering that USFK was the major deterrence to security threats from North Korea during the last half century, this survey result was very alarming. This result showed an overall discontent with the ROK-U.S. alliance and rising anti-American sentiments may undermine the legitimacy of the ROK-U.S alliance.

In the February 2004 survey, however, support for "immediate withdrawal" and for "gradual withdrawal" of USFK dropped from 6.3 to 3.8 percent and from 44.6 
to 33.1 percent, respectively. The proportion of those in favor of "extended presence" and "continued presence" increased from 21 to 27.1 percent and 27 to 34.3 percent, respectively. This indicates that the level of discontent with USFK was sharply reduced and favorable attitudes toward USFK increased substantially.

Figure 5. Ciangle in Aititude ON USFK

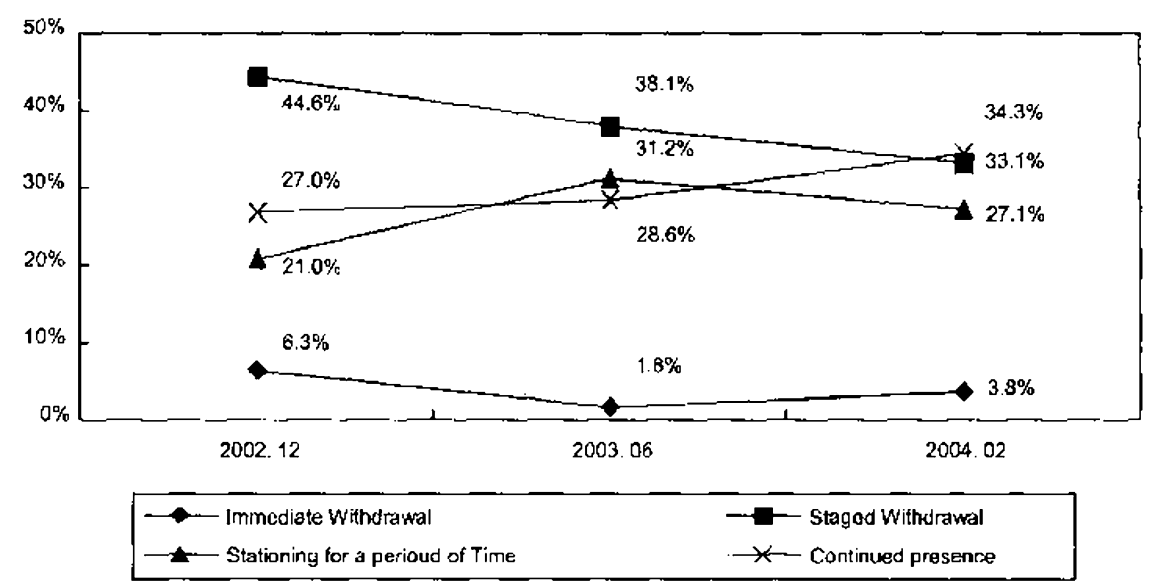

SOURCE: EAI and Jonng-Ang Ilbo (2002, 2003) and EAl and HanKook Ilbo (2004).

* Those Responses of "Don't know" and "No response" are exchuded.

In short, the majority of Koreans ( $71 \%$ in $2002,81 \%$ in 2003 and 2004$)$ are very cautious about dismantling the traditional ROK-U.S. alliance. They have a sense of hesitation or apprehension toward the fundamental rupture of Korea-U.S. relations. These results show that the recent surge of anti-American sentiment in South Korea has not posed any teal threat to the alliance between Seoul and Washington. With more than 70 percent of the population favoring maincenance or strengthening of the alliance, it would be difficult to characterize the anti-Americanism in South Korta as challenging the legitimacy of the alliance.

\section{Divided Public Opinion on Lnited States}

Despite the recent trend of increasing support for the ROK-U.S. alliance, we can discern a division of attitudes of the Korean public towards the U.S. As shown in Figure 6, there is a sharp split between those who support and those who oppose the Bush administration's hard-line policy on North Korea. This result indicates that among the Korean public there are two conflicting perceptions regarding the United States. While some Koreans perceive the United States as a reliable ally to guarantee the national security, others hold an opposing view that the United States is an impediment to the rapprochement between Senul and Pyungyang. The divided perceptions on the United States seem to he closely related to the conflicting views towards 
North Korea. There have been two conflicting attitudes cowards North Korea: enthusiasm towards North Korea as a partner for rapprochement and reunification, and a lingering mistrust of North Korea as an enemy.?

Ficure 6. Attitude on Bush's Hardliner Policy Towards DPRK

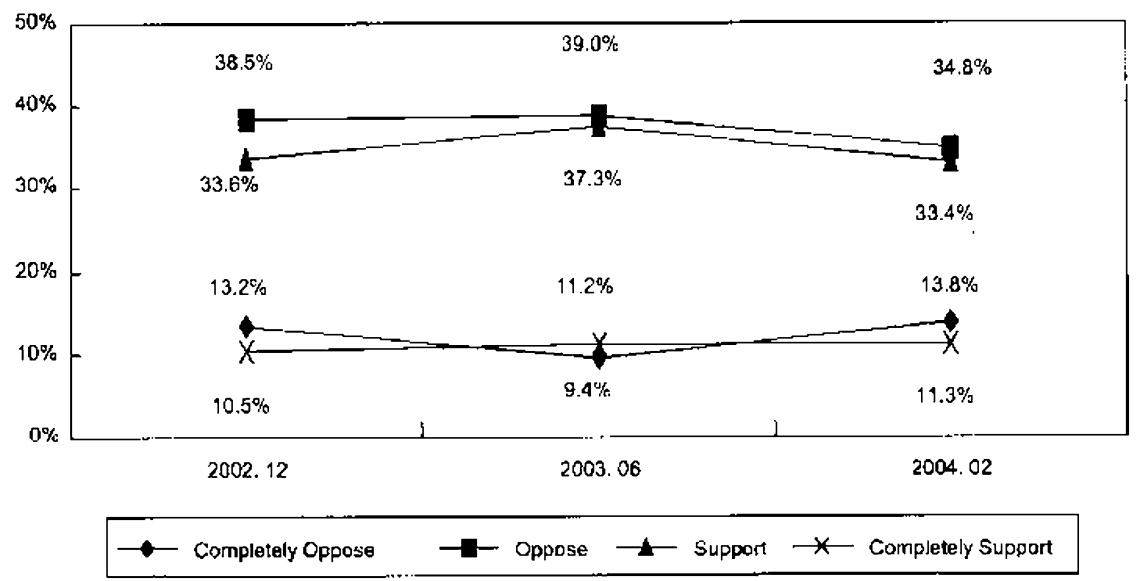

SOURCE: EAl and Joong-Ang Ilbo (2002, 2003) and EAI and HanKook Illoo (2004).

* Those Responses of "Don't know" and "No response" are excluded.

Firitre 7. Feeling ThFmomethr Towards the US

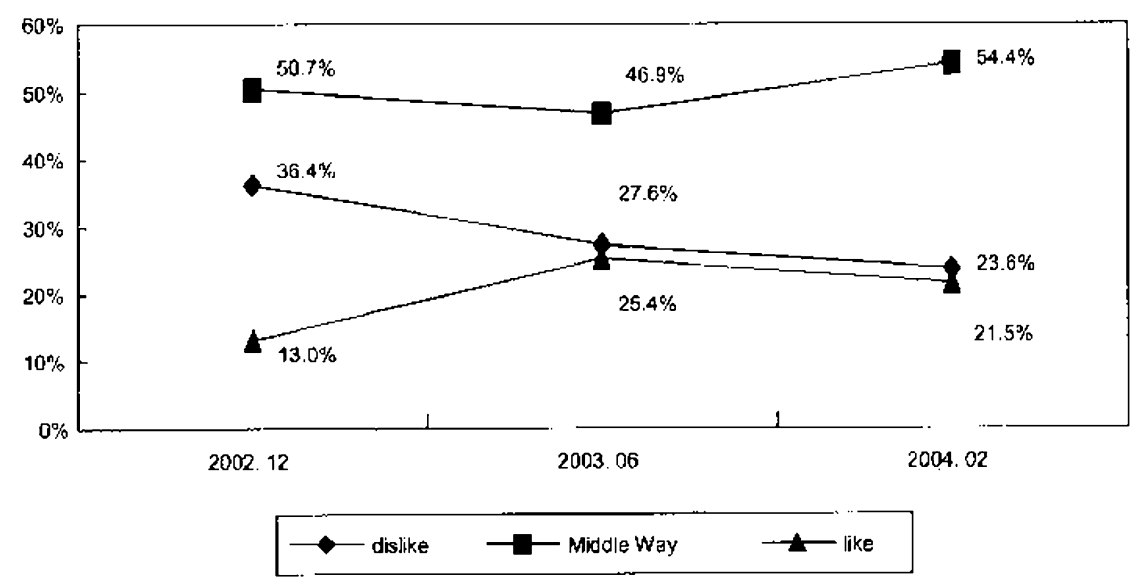

SOURCE: FAI and Joong-Ang Ilbo (2002, 2003) and EAI and IlunKook Ilbo (2004).

* Those Responses of "Don't know" and "No response" are excluded.

'The divided public opinion towards the U.S. is also found in the Korean public's general feelings towards the United States. As shown in Figure 7, in December 2002, the number of those who dislike the U.S. (36.4 percent) were much larger than those who likc (13percent), while almost 50.7 percent were neutral. In 2003 and 
2004 survey, there was a significant change of Korenns' feeling toward the U.S. Those who like or dislike the U.S. were of almost similar proportion. This result indicates that while a favorable feeling toward the L.S. has increased substantially during the last two years, the Korean public is still divided in their general feeling toward the U.S.

\section{WANING ANTI-AMERICANISM IN SOUTH KOREA: WHO HAS CHANGED?}

In the previous section, opinion poll results indicate that the attitude of the Korean public as a whole toward the U.S. has changed substantially and anti-Americanism has been subdued significantly. In this section, I analyze who changed their opinion and how did that change take place. In order to answer these questions, we have conducted a comparative analysis of the average responses according to political views and age groups on issues directly related to the ROK-U.S. alliance, such as "what is a desirable ROK-U.S. alliance" and "withdrawal and reduction of USFK." By this comparative analysis, we also can examine whether the polarization of public opinion on the U.S. has continued or been diluted.

Comparing the average values by age group in the Dccember 2002 poll, responses from people in their twenties and thirtics lcaned towards an endorsement of a reduction of USFK with 2.34 and 2.46 , respectively, while a preponderance of responses from people in their forties and fifties (2.7/4 and 3.22, respectively) were in favor of the continued presence of USFK. This survey result indicates that there was a sharp polarization of attitude toward the U.S. according to different age groups.

'Table 1. Mean Test Between Glnerations on the attitude toward the U.S.

\begin{tabular}{|c|c|c|c|c|c|c|}
\hline \multirow{2}{*}{ Issue } & \multirow{2}{*}{$\frac{\text { ANOVA }}{\text { Gencration }}$} & \multicolumn{2}{|c|}{ December 2002} & \multicolumn{2}{|c|}{ February 2004} & \multirow{2}{*}{$a-b$} \\
\hline & & Meivl-a $\left(N^{\prime}\right)$ & Grouping & Mean-b (N) & Grouping & \\
\hline USEK & $20 \mathrm{~s}$ & $2.34(264)$ & $20 \mathrm{~s} 130 \mathrm{~s}$ & $2.71(200)$ & & -0.37 \\
\hline (1-score Scale) & $30 \mathrm{~s}$ & $2.16(276)$ & vs. & $2.6(\times 257)$ & $20 s+30 s+40 s$ & -0.20 \\
\hline Median 2.5 & $40 \mathrm{~s}$ & $2.74(202)$ & $40 \mathrm{~s}$ & $3.02(237)$ & vs. & -0.28 \\
\hline Continued Presence (4) & More than 50 & $3.22(277)$ & vis. & $3.29(288)$ & Nore than 50 & -0.07 \\
\hline Immediate Withdrawal(1) & Total & $2.69)(1019)$ & More than 50 & $2.94(982)$ & & -0.25 \\
\hline US-ROK Alliance & $20 \mathrm{~s}$ & $4.02\{264\}$ & & $4.8 ?(200)$ & $20 s+30 s$ & -0.85 \\
\hline (10-score Scale) & $30 \mathrm{~s}$ & $4.27(276)$ & $20 s+30 s+40 s$ & $4.88\{256\}$ & vs. & -0.61 \\
\hline Median 5 & $10 \mathrm{~s}$ & $4.93\langle 209)\rangle$ & vs. & $5.39(238)$ & $40 \mathrm{~s}$ & -0.46 \\
\hline Strong Alliance (10) & More then 50 & $5.89(281)$ & More thrum 50 & $6.41(287)$ & vs. & -0.52 \\
\hline Independent Diplimacy(0) & Total & $4.78(i 030)$ & & $5.45(981)$ & More than 50 & -0.67 \\
\hline
\end{tabular}

SOURCE: a. EA1-Jongang Ilbo Survey Poll (December 2002 and February 2001).

b. Thure Responses of "Don't kruw" and "No response" are excluded.

c. Grouping Methort: Scheffic 
The February 2004 poll results suggest that there has been a visible trend towards conservatism among those in their twenties and thirties, showing the value of 2.71 and 2.66, respectively. When looking at the average difference, people in their twenties showed the biggest swing toward conservatism with 0.37 .

As for the question about the ROK-U.S. relations in the poll of December 2002, the responses from people in their twenties, thirties, and fortics werc all on the left side of the median value of 5 on the scalc with $4.02,4.27$, and 4.93 , respectively, showing a strong preference for national defense autonomy, while the value for those in their fifties and above was 5.89 , showing a strong support for maintaining and strengthening of the ROK-U.S. alliance.

The average margin of difference between December 2002 and February 2004 for those in their twenties and thirties $(0.85$ and $0.6 \mathrm{l}$, respectively) was much wider than those in their forties, fifties and above $(0.46$ and 0.52 , respectively). In other words, there has been an overall trend towards conservatism among different age groups during the last two years and what is remarkable is the change in attitude among those in their twenties and thirties, whose margin of change signifies a turnatout in their political positions, from progressive to conscrvative.

Comparing the average value of people's attitudes towards the U.S. by their different political oricntations (as shown in Table 2), the change found among different age groups is similar to the trend towards conservatism. Progressives were close to the middlc-road position with 2.51 point on issues regarding USFK in December $2002 \mathrm{~s}$ poll, the moderates 2.69 , and the conservatives, with the most conservative position, at 2.86. In the February 2004 poll, the progressives and conservatives showed a remarkable swing towards conservatism with 2.74 and 3.18. On the ROK-U.S. relations, the progressives showed a higher preference for national defense autonomy in 2002 with 4.32 (the moderates showed at 4.74 ), while the value for the same group in the 2004 poll shifted to the left of the mean value, to 4.85 .

Table 2. MEan Change in attitude Toward The U.S. by Idlology

\begin{tabular}{|c|c|c|c|c|c|c|}
\hline \multirow{2}{*}{ Issue } & \multirow{2}{*}{$\frac{\text { ANOVA }}{\text { Ideology }}$} & \multicolumn{2}{|c|}{ December 2002} & \multicolumn{2}{|c|}{ February 2004} & \multirow{2}{*}{$a-b$} \\
\hline & & Mean-a (N) & Grouping & Mean-b (N) & Grouping & \\
\hline \multirow{4}{*}{$\begin{array}{c}\text { USFK } \\
\text { (4-score Scale) } \\
\text { Median } 2.5\end{array}$} & Progressive & $2.51(30) 2)$ & Libcral & $2.74(208)$ & Liberal + & -0.23 \\
\hline & Central & $2.69(409)$ & vs. & $2.89(477)$ & Central & -0.30 \\
\hline & Conservative & $2.86(296)$ & Central + & $3.18(276)$ & $\mathrm{V}_{\mathrm{s}}$ & .0 .32 \\
\hline & Total & $2.69(100))$ & Conservarive & $2.94(961)$ & Conscrvative & .0 .25 \\
\hline \multirow{4}{*}{$\begin{array}{c}\text { ROK-US Alliance } \\
\text { (10-score Scale) } \\
\text { Median } 5\end{array}$} & Progressive & $4.32(303)$ & Lilseral † & $4.85(209)$ & Liberal + & -0.53 \\
\hline & Contral & $4.7 / 4(115)$ & Central & $5.21(478)$ & Central & -0.17 \\
\hline & Conservative & $5.32(292)$ & vs. & $6.33(277)$ & Vs. & -1.01 \\
\hline & Toral & $4.78(1018)$ & Conservative & $5.45(964)$ & Conservarive & -0.67 \\
\hline
\end{tabular}

SOURCF: a. EAI-Joongung Itbo Survey Poll (December 2002 and Irebruary 2004).

b. Those Responses of "Dun't know" and "No respunse" are excluded.

c. Girsuping Method: Scheffe 
In summary, there was an overall trend towards conservatism when comparing the results of the two polls conducted in December 2002 and February 2004, and one remarkable change was the conservative swing found among people in their rwenties and thirties who had represented the progressives during the last presidential election. As a whole, while the political attitudes of Korean people on the L.S. have moved toward the conservative end of the spectrum in general, such transition appears more conspicuously among previously anti-American camps, mainly the young generation, the progressive, and the supporters of Roh and Kwon.

However, with discrepancies in the average value among different age groups still present in the February 2004 poll, polarization of public attitude toward the U.S continues, though the degree of polarization has become less sharp in comparison to December 2002 survey result. While anti-American sentiments reached the highest point in December 2002 and waned substantially since then, a porentially scrious threat to the future of the ROK-U.S. alliance was the sharp polarization of public attitude toward the U.S. based on political sentiment, age groups, regions, and the presidential candidate supported by the respondent. In the winter of 2002 , anti-American sentiments manifested in candlelight demonstrations which were mainly organized by young generation, progressive NGOs, and Roh Moo-hyun supporters. Since then, the polarization of public opinion on security issucs, such as North Korea policy and the ROK-U.S. relations, has been the key cause of ideological conflict in South Korea and a major obstacke to gaining the national consensus required for promoting government's policy on North Korea and the ROK-U.S. relations. The conflict is likely to continue to plague South Korea for a long time.

Polarized public attitudes on security issues are most salient among different age groups. As for the reasons for the progressive tendencies among the South Korean young genetation, a number of explanations can be suggested. Firstly, because the young generation did not experience the Korean War and thus have a weak sense of threats from North Korea, they tend to downplay the ROK-U.S. alliance as a deterrent against North Korean threat. Secondly, because the young generation constitures the largest proportion of the Internet users and the Korean Internct media tend to be progressive in orientation, the young generation tends to harbor relatively strong anti-American sentiments. Finally, Roh Moo-hyun, who called for equal partnership in Korea-U.S. relations in his campaign promises and had the duminant support from young people, may have fueled anti-American sentiments among the young generation. ${ }^{10}$

\section{EXPLANATIONS FOR THE WANING ANTI-AMERICANISM}

What caused the rapid decline of anti-American sentiment over the last two years? Several important factors can be suggested. 


\section{The Rising North Korean Nuclear Threat}

The rising threat of nuclear development by North Korea has been a key factor reinforcing the conservative shift of the political atticudes toward the U.S. North Korea confessed its program to develop nuclear weapons (October 2002), broke the sealing on reactor fuel rods that would enable the extraction of plutonium, expelled IAFA insjectors (December 2002), and declared its secession from the Non Proliferation Treary (NPT) (January 2003). Moreover, it waned both the U.S. against the diplomatic and economic containment of North Korea (April 2003) and South Korea against the pressure on Pyungyang in collusion with the U.S. North Korea then moved on to making an intimidating remark that if South Korea continued to oppress North Korea, a grave calamity would be unavoidable (May 2003). This increase in North Korean aggressiveness enhanced the level of distrust concerning North Korea amotig the Korean public. 11

\section{The Reduction and Reallocation of USFK}

The reduction and reallocation of USFK has generated a sense of a security crisis among Koreans, which would in turn rcinforce the conservative voice among the Korean population. The reduction and reallocation of USFK had been on the agenda of the Department of Defense' since 1989 and Secretary Rumsfeld proposed U.S. troop reallocation in February 2003.

The U.S. has expedited the reduction and relocation of the 2nd Infantry Division of LSFK from north of Han River to south of it. This signaled the end of the 'trip wite' role of U.S. Second Division'12 'The USFK's automatic engagement upon North Korea's invasion on South Korca is no longer guatanteed. Korean conservatives soon followed up by claiming that anti-Americanism intensified the tension and cleavage in the ROK-U.S. alliance. They started to otganize civil movements with a slogan for the teconsolidation of the ROK-U.S. Alliance, the collapse of the Kim Jung-Il regime of DPRK and the opposition to anti-Americanism.

Conservatives of both the L.S. and South Korea began to express apprehension that the security crisis would bring about a negative impact on the fragile Korean economy. Moody's, a prominent credit rating agency, changed the outlook on Korea's long-term credit ratings from 'positive' to 'negative' in February 2003 due to the rising risk of national security. This raised public concems about the negative economic ramifications of uncertain security situations and helped emphasize the importance of ROK- U.S. alliance.

\section{President Roh's Switch to a Pragmatic Diplomatic Strategies}

After his inauguration in February 2003, President Roh switched to a pragmatic diplomacy, urging the public to refrain from holding demonstrations, explaining that 
the country was faced with the more pressing task of resolving the North Korean nuclear issue. The switch in his diplomatic approach was interpreted as President. Roh's intention to seek a solution to the nuclear threat through the ROK-U.S. alliance. This interpretation was affirmed by a series of moves that followed, such as the swift decision to send non-combat troops to Iraq and his unprecedented emphasis on the ROK-U.S. alliance in the South Korea-L.S. summit in April. The two leaders affirmed their commitment to solidifying bilateral ties, reaching an agrecment to scck a peaceful resolution and other concrete moasures for the nuklear issue. $\Lambda$ s discussed above, the conservative swing among the younger generation and former progressives was a remarkable change in the sudden reversal in public view of the U.S.; and, considering that these groups make up the key support base for President Roh, the change of opinion among these groups may have something to do with President Roh's switch to a pragmatic diplomacy. ${ }^{13}$

The dramatic transition of Roh's policy reached its peak when the decision for the dispatch of ROK forces into Iray was made in March 2003 and the summit talk with Bush was held. In the talk shared in April 2003, the two leaders agreed to consider "additional measures" to make DPRK give up its nuclear devclopment. Considering that most supporters of Roh were critical of war and the U.S., it is not surprising that this pragmatic change of Roh's policy raised scvere controversies among his supporters as well as his opponents.

The result, however, showed that $69 \%$ of respondents supported the decision to dispatch the Korcan forces to Iraq (very good 22\%, good 47\%), and over the majority (58\%) positively evaluated Roh's pro-American gestures and the agreement on tough measures proposed by the L.S. in the summit talk. 'Ihis means that the change in Roh's policy partiaily caused the changing attitudes of the supporters of Roh toward the U.S., which provides us with an important cluc to understanding the change in the political position toward the U.S. among the young and the progressive.

\section{The Changing Domestic Political Environment}

The wave of anti-Americanism had some correlation to the special circumstances surtounding the presidential election last year. The candidates' action had an impact on the public's anti-Ametican sentiments. Just hefore the presidential race moved into full swing, the presidential candidates jumped on the bandwagon of anti-Americanism that surged following the acquittal of the two U.S. soldiers. In addition to Kwon Young-ghil, candidate of the Democratic Labor Party, conservative candidate Lee Hoi-chang also joined the crowd by signing a nationwide petition sponsored by a civic group demanding revision of SOFA and a personal apology from U.S. President George W. Bush. He even considered the possibility of participating in a candlelight demonstration. ${ }^{14}$

Roh Moo-hyun also staked his campaign on continued engagement with North Korea and greater autonomy from the United States. During his campaign he was 
constantly appealing to the public by assuring that he would continue the sunshine policy, and demanded that South Korea and the U.S. stand on equal footing. In fact, the outpouring of anti-American sentiment appeared to give a strong boost to the candidacy of Mr. Roh who once advocated the outright withdrawal of the United States's 37,000 troops from South Korea.

There is a correlation between the waning anti-Americanism and people's disappointment with the Roh administration. Since his inauguration on February 15, 2003, President Roh enjoyed a shor honeymoon period. Like his prectecessors, high expectation for his government turned into disappointment within a short time. According to a Jovang Ilbo poll on the president's performance during his first year in office, only $15 \%$ of public expressed support for the president's performance and 80 percent answered that the general situation of Korea had worsened since his inauguration. ${ }^{15}$ The plummeting popularity of the Roh administration helped to enhance the conservative position favoring a stronger ROK-U.S. alliance, and it may have also helped the younger generation to form a more realistic perspective on KOK-U.S. relations.

\section{CONCLUSION}

The anti-Amencanism in South Kored that led some to chaim a crisis in the ROK-U.S. alliance in December 2002 has rapidly waned in the last two years. The popular attitude towards the U.S. has been rapidly shifting towards recognizing the legitimacy of the ROK-LJ.S. alliance. However, considering that there are still divided perceptions and attitudes towards the U.S. and North Korea, it would be a mistake to conclude that the crisis in the alliance has been completely resolved.

Even though we can be relieved from the trend of waning anti-Americanism, polarized public opinion is still a worrisome phenomenon. 'lherefore, we have to pay attention to the polarization of the political attitudes toward the U.S. and the possibility of it to develop iuto a scrious ideological conflict. Signs of such conflict have already appeared in the Korea society. On May 1 and Nugust 15 in 2003, both camps of conservatives and progressives respectively held demonstrations to show off their political prowess. While the Stars and Stripes flapped high by the conservative, it was torn into pieces by a group of radical students. Under these polarized public opinion toward the L.S., conflict and cleavage in Korean society will be maintained for a while.

The Korean public has undergone a great change in their perception toward North Korea and the U.S. While it is very difficult to predict where the change is headed, it is a clear truth that the future of the Korea-U.S. relationship would be obscure without sincere endeavors to improve the current asymmetry in the alliance itself and bridge the ideological and generational gaps of the Korcan society. When polarized public upinion on sccurity issues is left unresolved, generational and ideological conflict around security issues is likely to continue to plague South Korea, and may even impede efforts toward an effective North Korean policy and ROK-UJ.S. alliance. 


\section{REFERENCES}

Campbell, Converse, Miller and D.E. Stokes. 1960. The American Voter. New York: John Wiley \& Sons.

EAI - HanKook Ilbo. 2004. Public Opinion Survey on anti-Americanism on Koreat-the U.S. Relations Survey Data.

EAl - Joong-Ang llbo. 2003. Pablic Opinion Survey on anti-Amerianism on Korrea-the U.S. Relations Survey Data.

EAI $\cdot$ Jorng-Ang Ilbo. 2002. Public Opinion Survey on anti-Americanism on Korea-the U.S. Relations Survey Data.

Ha, Youngsun and Chaesung Chun. 200/. Nuclear Problem of North Kurea and Six Party Talks. NSP Report 1. Seoul: East Asia Institute (in Korean).

Han, Young-Sup. 2002. The Sunshine Policy and Security on the Korean Peninsula: A Critical Assessment and Prospects. In The Korean Peninsula in Transition: The Summit and its Aftermath, ed. Koh, Byung-Chul. Seoul: Kynngnam University Press.

Hollander, Paul. 1992. Anti-Americanism: Critiques at Home and Abmad, 1965-1990. Oxford: Oxford University Press.

Kang, Won-1'ack. 2002. Inter-Korean Relations and Elections: Why Didn't the Northem Wind Blow in the 2000 South Korean Legislative Election? In The Korean Peninsula in Transition: The Summit and its Aftrmath, ed. Koh, Byung-Chul. Seoul: Kyungnam University Press.

Kim, Byung-Kook, 2003. The U.S-South Korean Alliance: Anti-American Challenges. Journal of East Asian Studies 3 (2). Lynne Reiner.

Kim, Doh-Jong, 2002. The Politics of North-South Relations in the Shadow of Political North-South Relations in the Shadow of Political Cleavage, In The Korean Peninsula in Transition: The Summit and its Aftermuath, ed. Koh, Byung-Chul. Seoul: Kyungnam University Press.

Kim, Il Young and Sung-Yul Cho. 2003. USFK: History, Contradictions, and Prospect. Scoul: Han Ul Academy (in Korean).

Kim, Jin Wung. 1989. Recent Anti-Amcricanism its Suuth Korea. Asian Sumvey 29: 7/99-63.

Kim, Tae-Hyun. 1998. South Korean Perceptions and Policies on North Korea. Foreign Policies and National Integration. Sunam:Sejong Institue (in Korean).

Kim, Taehyun. 2002. Domestic Supports for the Korea-U.S. Alliance in the U.S. and Korea. In Korea-U.S. Relations in Transition: Korea-U.S. Alliance in Retrospect and Prospects for a New Strategic Partnership, ed. Baek, Jong-Chun and Lee, Sang-Hyun. Sungnam: The Sejong Institute.

Lce, Nac-Young and Ha-Kyung Lee, eds. 2003. Dilemma and Cboice of Rob Moo-Hyun Government. Seoul: East Asia Institute (in Korean).

Lee, Nas-Young and Han Wool Jeong. 2003. Anti-Americanism and the ROK-US Alliance. National Strategy 9 (3): 473-98. Seoul: The Sejung Institute (in Korean). Lee, Nae-Young. 2002. Generation and Political Idcology. Sasang, Fall, Scoul: Nanam 
(in Korean).

Lee, Sang-Hoon. 2001. The Security Circumstances of Korea Peninsular and the Role of USFK in 21th Century. Sungnam: The Sejong Institute (in Korean).

Lee, Sook-Jong. 2002. Sources of Anti-Americanism in Korean Society: Implications for Korean-U.S. Relations. In Korea-U.S. Relations in Iransition: Korea-U.S. Alliance in Retrospert and Prosterts for a New Sirutegic Partnership, ed. Baek, Jong-Chun and Lee, Sang-Hyun. Sungnam: The Sejong Institute.

Lew, Young Ick. 2004. A Historical Overview of Kosean Perceptions of the United States: Five Major Stereotypes. Korea Journal 44 (1): 109-51.

Pew Research Center For the People \& The Press. 2003. Views of a Changing World data.

Pew Research Center For the People \& The Press. 2002. Views of $A$ What the World Thinks in 2002 data.

Pollack, Jonathan \& Young Koo Cha, et al. 1995. A New Alliunce for the Next Contury: The Future of the U.S.-Korean Security Cooperation. Santa Monica: RAND.

Shin Gi-Wook. 1996. South Korean Anti-Americanism: A Comparative Perspective. Asian Survey 36 (8).

\section{ENDNO'TES}

On the historical development of anti-Americanism in South Korea, see Kim jin wung 1989) "Recent Anti-Amicanism in South Korea" Asian Survey 29: 7/9-63; Gi-Woo Shin 1\%9. "South Korean Anti-Americanism: A Compararive Perspectives." Sian Sunvy, 36: 787-903; Sook-Jong 1 pet. 2002. "Sources of Anti-Ameticanism in Korean Society: Implications for Korea-U.S. Relation." In Korea-U.S. Relationj in Transitim, eds Bick, Jong Chun and Sang Ityun Iee Sungnam: The Sejong, Institute: 16,2-80; Lew Young Ick 2004. "A Historical Overview of Korean Perceptions of the United States: Five Major Stereorypes." Kareu Joumal '1́1 (1): 109-151.

2 The surges of anti-Amerimanism were basced on the historical tuming points in North-South Korea relacions such as "high-level talks of South aud North Korea it 1991," "Junching the Korea Energy Development Organization (KEDO) for supportitg Nornt Korea to build ton-military nuclear plant," and "summit ralks berween South and North Kotea in 2002." Adversely, the decreases of negative opinion on the USFK used to be intluenced by the regress of the relation becween Seoul and Pyungyang or Pyung-yang and Washington: "A series of conflicts between North Korea and U.S. to uncover the veil of North Korea to develop clandestinc nucleat plants in 1999." "Nonh Korea Missile crisis in 1998," "sporadic skirmishes between South and North Korea such as two Sest Battles of Yun-Pyung (Seo-Hae-Kyo-Chun) in 1998 and 2002" and so on. On more detail information, see Lee, Vae-Young, 2003. "Polatization

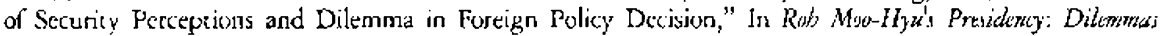
and Chrict, edi. Lee and Ha-Kyung Lee. Seoul: Nanam Publishers: 60-62 (in Korean).

"For more understanding of theargumen insisting that ROK-US alliance is cncountering a crisis, see Jeong and Lee Nat-Young. 2003. "Anti-Americanism and the ROK-IIS allianceNational Strateg 9) (3): 473-98.

1 See Kim, Byung-Kon. 2003. "The L'.S.-South Korean Alliance: Anti-America. Challenge." Jourral of East Asiun Stutite 3 (2): 225-58.

The data used in this atricle are from the EAI \& Joong Ang Daily Public Survey on Anti-Americanism in Dec. 2002 and Jun. 2003 and the EAI \& Han Konk Daily Survey on Anti-Americanism in leb.20044. These surveys were conducted by the telephone interviews. The sample size of three surveys is 1030 , 1032 , and 1000, respectively and the samples were selected through classified tandom sampling method.

"On the gencrational pojlitics and idenhgical condicts in South Korea, consule Nare-Young Lee 2002. "Generation and Policical Iderology," Sasang Fall, Seoul: Nanam.

7 For more detail, refer to Sang-Hoon Lcc, The Security Circumstances of Korea Peninsular and the Role of USFK in 2.1th Contury, (Sungram: The Sejong Institure, 2001). (in Korean)

8 After the accident, Non-governmental organizations (NGOs) leading the protests demanded Bush's public apology, a chorough investigation, and the assignment of judicatory rights from L.S. authotity to Koteats, 
The judicature of USFK, however, refused these demands and even hesicated to transfer the two suspected sergeants to a Korean investigation squad, with an intention to hand them ovet after thtec weeks froms the arcident. Besides, the U.S. military court judged them not guilty despite the inconsistcncy found in their testimonies about the acrual scenes of the incident, respertively on November 21 and $23,200$. Novemb:t 26, 2002, Dong-A Ilbo.

9 It doesn't mean that the South Korean perception on North Korea completely reversed from hostility to friendship. According to the analysis of Tac-l Tyun Kim, it includes dualism coexisting both of hostility and amiability atritude. Tar-Hyun Kim. 1998. "South Kurean Perreptions and Policics on North Korca." Forign Policies and National Integration, Sunam: Sejong Institue.

"Due to the rapprochement lxtween Scoul and Pyungyang, there has been a shift of perceptions of South Koreans, especially among the young generation, toward the UJ.S. from that of "the patton of security coarl inpedinest' to "the rapprochement between Seoul and Pyungyang."

' Ha, Youngsun and Chaesung (hun. 2001. "Nuclear Problem of North Korea and Six Party Talks." NSP Repor 1. Seoul: East Asia Institute. (in Korean).

:2 June 7, 2003. Hankyorch Shinmun.

This thange can be confirmed in the June 2003 poll to the question of Pteseident Roh's policy tuwards the U.S., whose average was 6.01: showing a sudden change from 5.23 in the 2002 December poll. ${ }^{7}$ On this change in the clectoral campaign of Lee Hoi Chang camp, most conservative newspapers such as Cho-Sun llbo intensively criticized Les anti-American campaigning strategy.

${ }^{15}$ For the more specific iniornation aboue die poll, sec EARS Reporl 1, liast Asia Institure, 2004. 